\title{
Estudio del comportamiento de diversos residuos de catalizadores de craqueo catalítico (FCC) en cemento Portland
}

\section{Studies on the behaviour of different spent fluidized-bed catalytic cracking catalysts on Portland cement}

\author{
J. Payá(*), M. V. Borrachero(*), J. Monzó(*), L. Soriano(*)
}

Recepción/Received: 29-V-08

Aceptación/Accepted: 9-I-09

Publicado online/Online publishing: 24-XI-09

\section{RESUMEN}

El catalizador de craqueo catalítico (FCC) es un residuo de la industria del petróleo que posee una elevada reactividad puzolánica y en matrices cementicias mejora de manera importante los aspectos mecánicos así como de durabilidad. En este trabajo se realiza un estudio comparativo sobre residuos de catalizador de distintos orígenes, para poder conocer si se pueden utilizar conjuntamente de forma indiscriminada o por el contrario hay que catalogarlos según su origen. Para ello, se realizó un estudio sobre cinco residuos de catalizador de craqueo catalítico distintos, suministrados por diferentes empresas y se estudiaron sus características fisicoquímicas, reactividad puzolánica a través de estudios termogravimétricos y la evolución de las resistencias mecánicas en morteros. Tras analizar todos los aspectos se concluye que no existen diferencias significativas entre los distintos catalizadores empleados.

Palabras clave: Análisis termico, difracción de rayos $\mathrm{X}$, Hidratacion, Puzolana, Resistencia a compresion.

\section{SUMMARY}

The fluidized-bed catalytic cracking catalyst (FCC) it is a residue from the industry of the petroleum that shows a high pozzolanic reactivity and, in cementing matrix, it significantly improves their mechanical behaviour as well as durability. In this research a comparative study on residues of catalyst from different sources has been carried out, in order to know if these residues can be used jointly in an indiscriminate way or, on the contrary, it is necessary to classify them according to their characteristics. Thus, a study on five different FCC residues, supplied from different companies, has been carried out, and their physical-chemical characteristics, pozzolanic reactivity by means of thermogravimetric analysis and the evolution of the mechanical strength of mortars were studied. After analyzing all the aspects, it can be concluded that no significant differences among the different tested catalysts were found.

Keywords: Thermal analysis, $X$-ray diffraction, hidration, pozzolan, compressive strength.

(*) ICITECH, Instituto de Ciencia y Tecnología del Hormigón. Universidad Politécnica de Valencia (Valencia). 


\section{INTRODUCCIÓN}

La industria de la construcción lleva varias décadas incorporando el uso de materiales cementantes y puzolánicos para obtener matrices conglomerantes más económicas, ecológicas y con mejores prestaciones. En este sentido se han utilizado materiales puzolánicos de origen agrícola (ceniza de cáscara de arroz), industrial (ceniza volante y humo de sílice) e incluso puzolanas de síntesis (metacaolín) (1-6).

El uso de catalizadores de craqueo catalítico en lecho fluidizado (FCC) se ha extendido durante los últimos años a muchas plantas petroquímicas, dado el interés en la obtención de fracciones ligeras de hidrocarburos (naftas). Las características fisicoquímicas y catalíticas de los catalizadores FCC dependen del fabricante y de la planta de craqueo, por lo que en principio podría haber diferencias entre los residuos de este catalizador dependiendo del reactor (7-8).

La primera referencia encontrada sobre la reutilización del residuo de catalizador de craqueo catalítico (FCC) se remonta a 1995, en la que Escardino y col. (9), lo utilizan como sustituto del caolín en la preparación de fritas cerámicas.

A partir del año 1995 hasta la actualidad, el FCC se ha estudiado en el campo de la Ingeniería Civil, en especial como material puzolánico. Sus características fisicoquímicas y su composición silicoaluminosa hicieron pensar que podría actuar puzolánicamente y, por tanto, tratarse de una puzolana muy activa (10). Los múltiples estudios realizados por diversos grupos de investigación han corroborado que el FCC actúa como una puzolana activa desde las primeras edades de curado y que favorece el comportamiento mecánico y la durabilidad de las pastas, morteros u hormigones que lo contienen (11-16). En todos estos trabajos recogidos en la bibliografía hasta el momento, sólo se ha trabajado con residuo de un único origen para cada uno de ellos, aunque distinto entre los diferentes grupos de investigación.

El objetivo principal del presente estudio es comparar la reactividad y las características fisicoquímicas de cinco residuos de catalizadores de craqueo catalítico procedentes de sendos reactores en plantas petroquímicas diferentes, y valorar su posible utilización conjunta como un único residuo, sin distinguir su origen.

\section{EXPERIMENTAL, MÉTODOS Y MATERIALES}

El desarrollo experimental se divide en tres apartados, en el primero de ellos se estudian las características fisicoquímicas de los cinco residuos de catalizador. Posteriormente

\section{INTRODUCTION}

The industry of the construction takes several decades incorporating the use of cementing and pozzolanic materials to obtain mainly more economic, more ecological and better performance binders. In this way pozzolanic materials from agricultural activity (rice hush ash), industrial activity (flying ashes and silica fume) and even synthetic pozzolans (metakaolín) have been used (1-6).

The use of fluidized-bed catalytic cracking catalysts (FCC) has extended during the last years to many petrochemical plants, due to the interest on the yielding low molecular weight hydrocarbon fractions (naphthas). The physical-chemical and catalytic characteristics of the FCC catalyst depend on the supplier company and on the industrial plant, and consequently differences among the behaviour of catalyst residues would be found depending on the reactor (7-8).

The first bibliographic reference on the reusing of the catalytic cracking catalyst residue (FCC), was at 1995: Escardino et al. (9) study its use as substitute of the kaolin in the preparation of ceramic frits.

From 1995 until the present time, the FCC has been studied in the field of the Civil Engineering, particularly as pozzolanic material. Its physical-chemical characteristics and its silicoaluminous composition let to think that it could act as a pozzolan and, therefore, to be a very active pozzolan (10). Numerous studies carried out by several research groups have confirmed that the FCC acts like an active pozzolan from early ages of curing and enhances the mechanical behavior and the durability of pastes, mortars or concretes that contain FCC (11-16). In whole these papers, only one selected residue from an industrial plant was studied in each research, although different among the different research groups.

The main goal of the present study is to compare the reactivity and the physical-chemical characteristics of five residues of catalytic cracking catalysts coming from both reactors from different petrochemical plants, and to evaluate their use as a whole.

\section{EXPERIMENTAL, METHODS AND MATERIALS}

The experimental study has been divided in three sections. In the first of them the physical-chemical characteristics of the five catalyst residues are studied. 
se analiza por termogravimetría la actividad puzolánica de los residuos de catalizador, en pastas de cemento sustituidas con un $15 \%$ de cemento por dichos residuos. Por último, se realizaron morteros de cemento, con un $15 \%$ de sustitución de cemento por los distintos catalizadores (CAT), al objeto de comparar su influencia en el comportamiento mecánico.

\subsection{Materiales}

\subsubsection{Catalizadores utilizados}

Se utilizan cinco residuos de catalizador de craqueo catalítico de diversas empresas petroquímicas. El residuo de catalizador denominado CAT1 fue suministrado por la empresa BP OIL desde su planta del Grao de Castellón. Los residuos de catalizador CAT2 y CAT3 los suministró la empresa Cepsa procedentes de sus plantas de Huelva y Algeciras, respectivamente. $Y$ por último, los residuos de catalizador CAT4 y CAT5 fueron suministrados por Repsol sin ser identificada su planta de origen.

\subsubsection{Cemento}

El cemento utilizado en la preparación de las pastas y morteros fue un cemento CEMI 42.5R suministrado por CEMEX de su fábrica de Buñol (Valencia-España).

\subsubsection{Preparación de mezclas}

Para los análisis termogravimétricos se fabricaron pastas sólo de cemento y de cemento/CAT, mediante el siguiente procedimiento: se mezclan perfectamente la cantidad de cemento con la puzolana para las pastas cemento/CAT, o se pesa la cantidad de cemento correspondiente en caso de la pasta control, en un recipiente cilíndrico de plástico con cierre hermético; se añade el agua indicada para la experiencia y se mezcla hasta obtener una pasta homogénea; posteriormente se cierra el recipiente y se mantiene en la cámara húmeda $\left(20^{\circ} \mathrm{C}\right)$ hasta la edad de curado escogida para el ensayo. A la edad de curado determinada, se extrae una muestra y se muele en un mortero de ágata con acetona, para detener el proceso de hidratación. Esta muestra se filtra y se seca durante una hora en una estufa a $60{ }^{\circ} \mathrm{C}$. Por último, se pasa por un tamiz de $80 \mu \mathrm{m}$ y ya queda preparada para su posterior análisis por termogravimetría.

Los morteros de cemento se realizaron según las especificaciones exigidas por la norma española para el amasado de este tipo de morteros (17). Se siguió el procedimiento de la norma UNE-EN 196-1 (17), donde se describe el método de amasado y los ensayos de resistencias mecánicas. En la elaboración del mortero se utiliza un árido silíceo de módulo de finura 3,34. La relación agua/conglomerante fue de 0,5
In second place their pozzolanic activity was analyzed by means of thermogravimetric studies on cement pastes, in which $15 \%$ cement replacement by these residues. Thirdly, cement mortars, with $15 \%$ of cement substitution by the different catalysts (CAT) were prepared in order to compare their influence on the mechanical behavior of mortars.

\subsection{Materials}

\subsubsection{Catalyst residues}

Five residues of spent catalytic cracking catalysts from diverse Spanish plants of petrochemical companies were used. The residue CAT1 was supplied by the BP OIL company from its plant in Grao de Castellón. The residues CAT2 and CAT3 were supplied by Cepsa company from their plants in Huelva and Algeciras, respectively. And lastly, the residues CAT4 and CAT5 were supplied by Repsol without being identified their source plant.

\subsubsection{Cement}

The cement used in the preparation of the pastes and mortars was a CEMI 42.5R cement supplied by CEMEX from its factory in Buñol (Valencia-Spain).

\subsubsection{Preparation of mixtures}

For the thermogravimetric analyses, plain cement paste and cement/CAT pastes were manufactured, by means of the following procedure: cement was perfectly mixed with the pozzolan for cement/CAT pastes, or the quantity of corresponding cement is weighed for control paste, in a cylindrical plastic container with hermetic closing. The corresponding water quantity is added depending on the experience and solid and liquid was mixed until obtaining an homogeneous paste. Afterwards the mix was put into the container and stored in the moisture room $\left(20^{\circ} \mathrm{C}\right)$ until the age of curing chosed for the test. For a given curing age, a sample of paste is taken and milled in an agate mortar with acetone, to stop the hydrating process. This ground sample was filtered and dried off during one hour at $60^{\circ} \mathrm{C}$. Finally, it was sieved on $80 \mu \mathrm{m}$ sieve and it was already prepared for further thermogravimetric analysis.

The cement mortars were carried out according to the specifications in Spanish standard (17). The followed procedure was according to UNE-EN 196-1 (17), where the mixing method and mechanical strength test are described. In the preparation of the mortar, a siliceous aggregate of fineness modulus of 3.34 is used. The water / binder relationship was 0.5 , being the binder as 
siendo el conglomerante la suma de cemento Portland y puzolana. La dosificación empleada en la fabricación de morteros se detalla a continuación en la Tabla 1. the portland cement plus pozzolan weigths. The mixtures for mortars are summarized in Table 1.

Tabla 1 / Table 1

Dosificación de los morteros de sustitución de cemento por residuo de catalizador. Mortar mixtures replacing cement by spent catalyst.

\begin{tabular}{|c|c|c|c|c|}
\hline & CEMI42.5R (g) & FCC (g) & Árido (g) / Aggregate & $\mathbf{H}_{\mathbf{2}} \mathbf{O}(\mathbf{g})$ \\
\hline Control / Control & 450 & - & 1350 & 225 \\
\hline $\begin{array}{c}\text { Morteros con CAT / } \\
\text { Mortars with CAT }\end{array}$ & 382.5 & 67.5 & 1350 & 225 \\
\hline
\end{tabular}

\subsection{Técnicas y metodologías de ensayo}

\subsubsection{Composición química}

El análisis de la composición química de los residuos de catalizador se realizó empleando un equipo de fluorescencia de Rayos X modelo Philips MagiXPRO. La preparación de la muestra o pastilla de análisis se llevó a cabo fundiendo 8 gramos de tetraboruro de litio con un gramo de residuo de catalizador. La mezcla sólida fue fundida siguiendo el procedimiento convencional, aportado por el equipo de preparación de pastillas, modelo Vulcan 4M-Fusion Machina Type VAA 4.

\subsubsection{Difracción de Rayos $X$}

Para la caracterización mineralógica se realizó un análisis por Difracción de Rayos X (DRX) empleando un difractómetro modelo Philips PW1710 Based, donde se ha utilizado la radiación $\mathrm{K}_{\alpha}$ del $\mathrm{Cu}$ y un monocromador secundario (filtro de Níquel), que elimina la radiación $\mathrm{K}_{\beta}$ de $\mathrm{Cu}$. La intensidad y el voltaje del tubo generador de rayos $X$ se ajustaron en todas las medidas a $20 \mathrm{~mA}$ y $40 \mathrm{KV}$, respectivamente. Se registraron los difractogramas para el intervalo $2 \theta$ entre 5 y $60^{\circ}$, con un ángulo de paso de 0,02 y un tiempo de acumulación de 2 segundos.

\subsubsection{Análisis granulométrico}

Las medidas de granulometría por difracción láser ( $A D L$ ) de los distintos residuos de catalizador se realizaron con un equipo Malvern Instruments, modelo Mastersizer 2000. El rango del equipo es de 0,02 a 2000 micras. Las medidas se realizan en un medio acuoso y a las suspensiones se les aplica previamente un minuto de ultrasonidos, con la sonda propia del equipo, para disgregar posibles aglomerados de partículas.

\subsubsection{Espectroscopia Infrarroja}

Se registraron los espectros de infrarrojo por Trasformada de Fourier (FIIR) utilizando un espectrómetro Mattson Genesis II F.T.I.R, y se analizaron usando el software analítico del

\subsection{Techniques and methodologies}

\subsubsection{Chemical composition}

The chemical composition of the catalyst residues was carried out using a Philips MagiXPRO X-ray fluorescence model. The preparation of the sample was carried out fusing 8 grams of lithium tetraboride with $1 \mathrm{gram}$ of catalyst residue. The solid mixture was fused following the conventional procedure, by means of Vulcan 4Mfusion Machina Type VAA 4 model.

\subsubsection{X-Ray diffraction}

For the mineralogical characterization $X$-ray diffraction analysis (XRD) was carried out using a Philips PW1710 Based diffratometer, where the $\mathrm{Cu}-K_{\alpha}$ radiation and a secondary monocromator (filter of Nickel) that eliminates the radiation $K_{\beta}$ of $\mathrm{Cu}$ were used. The intensity and the voltage of the generating tube of $X$-rays were adjusted in all the measurements at $20 \mathrm{~mA}$ and $40 \mathrm{KV}$, respectively. Diffractograms were registered in the $2 \theta$ range between 5 and $60^{\circ}$, with 0.02 angle step and $2 s$ acquisition time.

\subsubsection{Granulometric Analysis}

Diffraction laser analysis (DLA) on the different catalyst residues were carried out using a Malvern Instruments Mastersizer 2000. The range of measurement was from 0.02 to 2000 microns. The measures are carried out using a water suspension, and a minute of ultrasounds was applied to the suspensions before the measurement, using the ultrasound probe of the equipment, to disintegrate agglomerated particles.

\subsubsection{Infrared Espectroscopy}

Fourier Transformed Infrared spectra (FTIR) were measured using a Mattson Genesis II spectrometer, and they were analyzed using WinFIRST-FTIR analytic 
equipo, que utiliza el programa WinFIRST-FIIR. El sistema dispersante para la fabricación de las pastillas a analizar por I.R. fue $\mathrm{KBr}$, que constituye un blanco para la zona espectral de 4.000-400 $\mathrm{cm}^{-1}$; las pastillas se realizan mezclando íntimamente trazas de la muestra, con $\mathrm{KBr}$ puro y seco en una proporción aproximada de 1:200 y comprimiendo la mezcla homogénea mediante una prensa.

\subsubsection{Análisis térmico}

Los análisis termogravimétricos se realizaron utilizando un módulo TGA 850 Mettler-Toledo, que permite realizar medidas hasta $1.100^{\circ} \mathrm{C}$. Este equipo permite medir simultáneamente la curva termogravimétrica y la curva de análisis térmico-diferencial (DTA). Para el análisis de las puzolanas se utilizaron crisoles de alúmina de $70 \mu \mathrm{l}$ con tapa con un orificio, y el intervalo de temperaturas escogidas fue entre 35 y $1.000{ }^{\circ} \mathrm{C}$, con una velocidad de calentamiento de $20^{\circ} \mathrm{C} / \mathrm{min}$ y atmósfera de aire seco con un flujo de $75 \mathrm{ml} / \mathrm{min}$. Para el análisis de las pastas de cemento con puzolana se emplearon crisoles de aluminio de $100 \mu \mathrm{l}$ con tapa sellable, la cual cuenta con un microagujero, que facilita la obtención de una atmósfera autogenerada de vapor de agua, lo que permite una mejor resolución de las curvas termogravimétricas. Para las pastas de cemento, el rango de temperaturas escogido fue de 35 a $600{ }^{\circ} \mathrm{C}$, utilizando una velocidad de calentamiento de $10^{\circ} \mathrm{C} / \mathrm{min}$ y una atmósfera de nitrógeno con un flujo de $75 \mathrm{ml} / \mathrm{min}$.

\subsubsection{Microscopía electrónica}

Por último se realizan ensayos de microscopia electrónica sobre los residuos de catalizador, empleando un equipo JEOL JSM6300. Las muestras fueron recubiertas en oro para facilitar la conductividad eléctrica de las mismas; dicho recubrimiento se realizó empleando el equipo BALTEC SCD 005, con un tiempo de exposición de 90 segundos, a una intensidad de $40 \mathrm{~mA}$ y una distancia de trabajo de $5 \mathrm{~mm}$. La presión a la que se realizó el proceso de recubrimiento fue de $2,4 * 10^{-2}$ mbar. El microanálisis se realizó con un equipo OXFORD INSTRUMENTS modelo Link-Isis. El programa de adquisición de rayos $X$ fue el $X$ Ray análisis y el programa para cuantificar, el SEM Quant, que utiliza el método ZAF. Finalmente, la adquisición de imágenes se realizó mediante el programa Autobeam.

\section{RESULTADOS Y DISCUSIÓN}

\subsection{Caracterización fisicoquímica}

\subsubsection{Composición química}

Las composiciones químicas de los distintos residuos de catalizador fueron determinadas por fluorescencia de rayos $X(F R X)$ y se muestran en la Tabla 2 . software of the equipment. Dried $\mathrm{KBr}$ was used for preparing pellets, in order to measure in the $4000-400 \mathrm{~cm}^{-1}$ range. The pellets were prepared mixing a small quantity of the sample with pure and dried $\mathrm{KBr}$ in an approximated proportion of 1:200 and compressing the homogeneous mixture by means of a press.

\subsubsection{Thermal analysis}

The thermogravimetric analyses were carried out using a TGA 850 Mettler-Toledo module that allows to carry out measurements up to $1100{ }^{\circ} \mathrm{C}$. This equipment allows to measure simultaneously the thermogravimetric curve and the differential thermal analysis curve (DTA). For the analysis of the pozzolans, $70 \mu$ l alumina crucibles were used with cover with a hole, in the 35 and $1000{ }^{\circ} \mathrm{C}$ temperature range, with $20^{\circ} \mathrm{C} / \mathrm{min}$ heating rate and dry air atmosphere with $75 \mathrm{ml} / \mathrm{min}$ flow. For the analysis of the cement pastes with pozzolan $100 \mu \mathrm{l}$ aluminum crucibles were used with sealed cover, which has a microhole that lets to get a water vapour autogenerated atmosphere, what allows a better resolution in thermogravimetric curves. For the cement pastes, the selected temperature range was $35-600{ }^{\circ} \mathrm{C}$, using $10^{\circ} \mathrm{C} / \mathrm{min}$ heating rate and a nitrogen atmosphere with $75 \mathrm{ml} / \mathrm{min}$ flow.

\subsubsection{Scanning electron microscopy}

Finally, Scanning electron microscopy studies on the catalyst residues were carried out using a JEOL JSM6300 equipment. The samples were gold recovered to facilitate the electric conductivity; this coating was carried out using a BALTEC SCD 005, with 90s exposure time, at $40 \mathrm{~mA}$ intensity and $5 \mathrm{~mm}$ distance. The pressure to which was carried out the coating process was of $2.4 * 10^{-2}$ mbar. The microanalysis was carried out using a OXFORD model INSTRUMENTS Link-Isis equipment. $X$ Ray analysis software was used for $X$-rays acquisition and SEM Quant software to quantify elements, which uses the ZAF method. Finally, the acquisition of images was carried out by means of the Autobeam software.

\section{RESULTS AND DISCUSSION}

\subsection{Physical-chemical characterization}

\subsubsection{Chemical composition}

The chemical compositions of the different catalyst residues were determined by $X$-ray fluorescence (XRF) and data are listed in the Table 2. 
Como se puede observar todas las composiciones químicas son muy similares y no existen diferencias apreciables entre los diferentes residuos. El contenido de $\mathrm{SiO}_{2}$ varía entre 45,46 y $49,60 \%$, mientras que el de $\mathrm{Al}_{2} \mathrm{O}_{3}$ lo hace entre 42,73 y $47,47 \%$. La suma de estos óxidos ácidos se encuentra en todos los casos entre el 92 y el $94 \%$, mientras que la relación entre $\mathrm{SiO}_{2}$ y $\mathrm{Al}_{2} \mathrm{O}_{3}$ es muy semejante, alrededor de la unidad, encontrando para las muestras CAT4 y CAT5 una mayor cantidad de $\mathrm{SiO}_{2}$ con respecto a la de $\mathrm{Al}_{2} \mathrm{O}_{3}$. En todas las muestras se han encontrado elementos de la familia de los lantánidos, que son óxidos metálicos típicos que se usan para formular las zeolitas existentes en estos catalizadores.
It can be observed that the chemical compositions for whole samples are very similar and significant differences among the different residuals are not found. The content of $\mathrm{SiO}_{2}$ varies between 45.46 and $49.60 \%$, and $\mathrm{Al}_{2} \mathrm{O}_{3}$ is between 42.73 and $47.47 \%$. The sum of these acid oxides in whole cases is found between 92 and $94 \%$, while the relationship between $\mathrm{SiO}_{2}$ and $\mathrm{Al}_{2} \mathrm{O}_{3}$ is very similar, near the unit, finding for the CAT4 and CAT5 samples a higher quantity of $\mathrm{SiO}_{2}$ with regard to $\mathrm{Al}_{2} \mathrm{O}_{3}$ one. For whole samples elements of the lanthanid family were found, which are typical metallic oxides that are used to formulate the zeolitic material in these catalysts.

Tabla 2 / Table 2

Composiciones químicas de los residuos de catalizador de craqueo catalítico. Chemical compositions for catalytic cracking catalyst residues.

\begin{tabular}{|c|c|c|c|c|c|}
\hline \% (Muestra seca) / \% (Dried sample) & CAT1 & CAT2 & CAT3 & CAT4 & CAT5 \\
\hline $\mathrm{SiO}_{2}$ & 46.04 & 45.80 & 45.46 & 48.78 & 49.60 \\
\hline $\mathrm{Al}_{2} \mathrm{O}_{3}$ & 47.47 & 46.93 & 46.73 & 43.32 & 42.73 \\
\hline $\mathrm{Fe}_{2} \mathrm{O}_{3}$ & 0.58 & 0.59 & 0.74 & 0.81 & 0.68 \\
\hline $\mathrm{CaO}$ & 0.11 & 0.07 & 0.07 & 0.07 & 0.03 \\
\hline $\mathrm{MgO}$ & 0.17 & 0.17 & 0.21 & 0.16 & 0.15 \\
\hline $\mathrm{SO}_{3}$ & 0.02 & 0.02 & 0.02 & 0.01 & 0.00 \\
\hline $\mathrm{Na}_{2} \mathrm{O}$ & 0.30 & 0.49 & 0.35 & 0.37 & 0.49 \\
\hline $\mathrm{K}_{2} \mathrm{O}$ & 0.02 & 0.02 & 0.02 & 0.04 & 0.05 \\
\hline $\mathrm{TiO}_{2}$ & 1.18 & 1.18 & 1.23 & 1.34 & 1.48 \\
\hline $\mathrm{P}_{2} \mathrm{O}_{5}$ & 0.01 & 0.01 & 0.01 & 0.01 & 0.01 \\
\hline $\mathrm{Na}_{2} \mathrm{O}_{3}$ & 0.04 & 0.07 & 0.07 & 0.25 & 0.12 \\
\hline $\mathrm{V}_{2} \mathrm{O}_{5}$ & 0.01 & 0.01 & 0.45 & 0.44 & 0.47 \\
\hline $\mathrm{La}_{2} \mathrm{O}_{3}$ & 1.33 & 1.03 & 1.20 & 0.83 & 1.25 \\
\hline $\mathrm{CeO}_{2}$ & 0.12 & 0.12 & 0.11 & 0.03 & 0.13 \\
\hline $\mathrm{Pr}_{2} \mathrm{O}_{3}$ & 0.19 & 0.14 & 0.17 & 0.27 & 0.43 \\
\hline $\mathrm{P} / \mathrm{LOI}^{*}(*)$ & 0.49 & 0.40 & 0.36 & 0.36 & 0.70 \\
\hline
\end{tabular}

$\left(^{*}\right)$ Pérdida al fuego / Loss on ignition.

La pérdida al fuego (P.F) en todos los casos fue inferior al $1 \%$ en peso, lo que es indicativo de que estos residuos no contienen partículas o depósitos de carbón que suelen aparecer en los procesos catalíticos de craqueo.

\subsubsection{Difracción de Rayos X (DRX)}

El análisis por Difracción de Rayos (DRX) representado en la Figura 1 muestra cómo todos los catalizadores contienen los picos correspondientes a una zeolita tipo faujasita $\mathrm{Na}_{2} \mathrm{Al}_{2} \mathrm{Si}_{4} \mathrm{O}_{12} .8\left(\mathrm{H}_{2} \mathrm{O}\right)$, así como la presencia minoritaria de mullita $\left(\mathrm{Al}_{6} \mathrm{Si}_{2} \mathrm{O}_{13}\right)$, tal y como se muestra sobre el difractograma del catalizador CAT1. No existen diferencias en cuanto a composición mineralógica entre los distintos catalizadores. La desviación en la línea base observada en la zona $2 \theta=15-30^{\circ}$ es característica de materiales amorfos, siendo más significativa para el catalizador CAT5.
In all the cases, the loss on ignition (LOI), was lower than $1 \%$ in weight, what is indicative that these residues do not contain particles or deposits of coal that usually appear in the cracking catalytic processes.

\subsubsection{X-Ray Diffraction (XRD)}

$X$-ray diffractograms represented in the Figure 1 , show that whole catalysts contain the peaks corresponding to a zeolite type faujasite $\mathrm{Na}_{2} \mathrm{Al}_{2} \mathrm{Si}_{4} \mathrm{O}_{12} .8\left(\mathrm{H}_{2} \mathrm{O}\right)$, as well as the minoritary presence of mullite $\left(\mathrm{Al}_{6} \mathrm{Si}_{2} \mathrm{O}_{13}\right)$, as marked on CAT1 diffractogram. No differences from the mineralogical composition among the different catalyst residues were observed. The deviation in the baseline observed in the $2 \theta=15-30^{\circ}$ range is characteristic of amorphous materials, being more significant for the CAT5. 


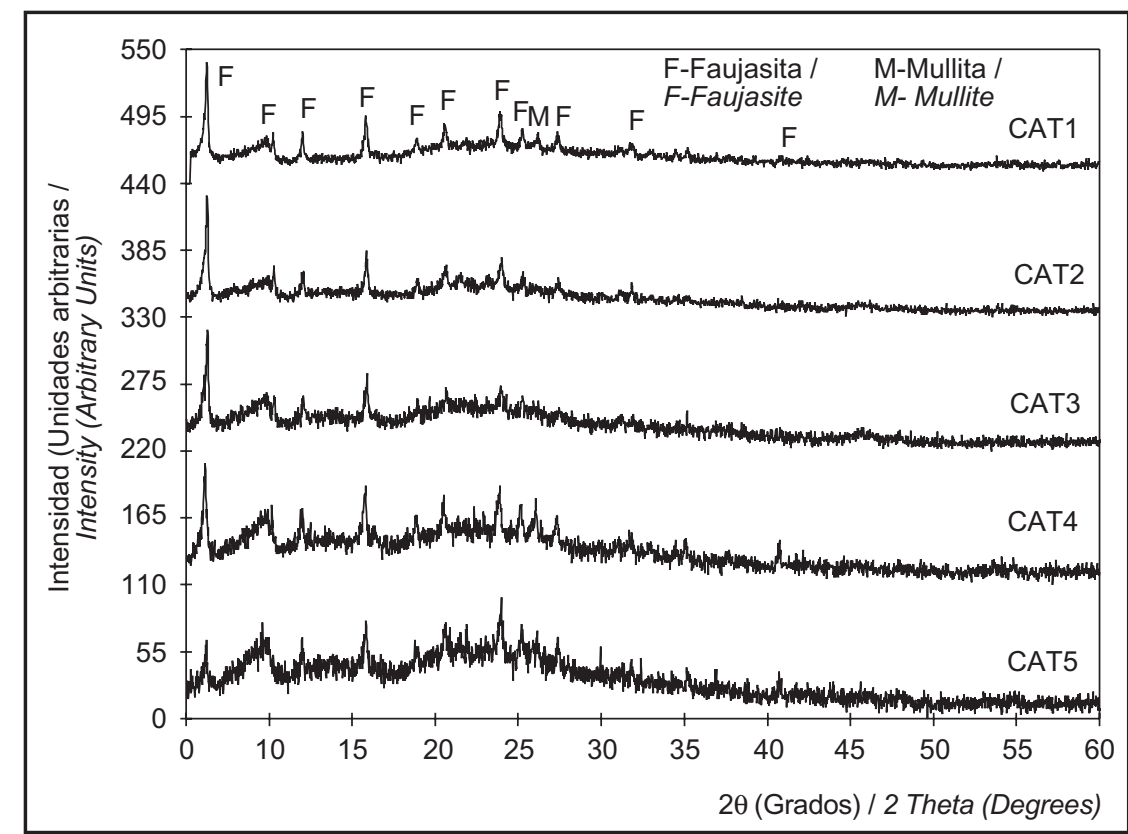

Figura 1. Difractogramas de RX de los diferentes residuos de catalizador de craqueo catalítico.

Figure 1. X-Ray diffractograms for catalytic cracking catalyst residues.

\subsubsection{Granulometría por difracción láser (ADL)}

En investigaciones previas se ha demostrado que la actividad del catalizador mejora notablemente cuando se somete a un proceso de molienda en un molino de bolas durante 20 minutos (10). Es por ello que a continuación se muestra en la Tabla 3 los principales parámetros granulométricos de los distintos residuos de catalizador en su estado original (CATX) y molido (CATX-20). En la Figura 2 se muestran las distribuciones granulométricas de los cinco residuos de catalizador en ambos estados. Se observa claramente cómo el proceso de molienda varía la granulometría del material original, desplazándose la curva granulométrica hacia tamaños de partícula inferiores. Se parte de una distribución unimodal (estado original) y se genera una distribución más amplia con dos hombros (estado molido), el primero de ellos centrado en 0,3-0,8 $\mu \mathrm{m}$ y el segundo entre 20-50 $\mu \mathrm{m}$.

En la Figura 2a se observa claramente que los residuos de catalizador muestran prácticamente la misma granulometría, con ausencia de partículas muy finas de menos de $10 \mu \mathrm{m}$ (ver Tabla 3). La activación mecánica por molienda da lugar a materiales muy finos como se demuestra en la Figura $2 b$. En todos los materiales molidos se observa una cantidad muy importante de partículas con diámetro inferior a 10 micras, que oscila ente el 40-50\% (ver Tabla 3). Por ello se puede asumir que el proceso de molienda (molino de bolas y 20 minutos de molienda) no produce tamaños diferentes, a pesar de los distintos orígenes de los diversos residuos de catalizador de craqueo.

\subsubsection{Diffraction Laser Analysis (DLA)}

In previous research, it has been demonstrated that the activity of the catalyst residue improves notably when it was ground in a ball mill during 20 minutes (10). In Table 3 the main granulometric parameters of the different catalyst residues in its original state (CATX) and milled (CATX-20) are summarized. In the Figure 2 the granulometric distributions of the five catalyst residues are shown in both states. It is observed clearly that milling process varies the grain of the original material, moving the granulometric curve toward lower particle sizes. From a unimodal distribution (original state), granulometric curve changes to a wider distribution with two shoulders (milled state), the first of them centered in the range 0.3-0.8 $\mu \mathrm{m}$ and the second one in the range 20-50 $\mu \mathrm{m}$.

As can be seen in the Figure $2 a$ the catalyst residues show the same particle distribution, with absence of very fine particles with diameter less than $10 \mu \mathrm{m}$ (see Table 3). The mechanical activation by milling gives place to very fine materials as it is showed in the Figure $2 b$. For whole the milled materials a very important quantity of particles with diameter less than $10 \mu \mathrm{m}$ is observed which was in the range $40-50 \%$ in volume (see Table 3). Thus, it can be assumed that the milling process (ballmill and 20 minutes of milling) does not produce different sizes, in spite of the different origin of the catalytic cracking catalyst residues. 
Tabla 3 / Table 3

Principales parámetros granulométricos de los residuos de catalizador en sus estados originales y molidos. Main granulometric parameters for catalyst residues in their original and their ground states.

\begin{tabular}{|c|c|c|c|c|c|}
\hline Residuo / Residue & $\begin{array}{c}\mathbf{d}_{\text {medio }}(\boldsymbol{\mu m}) / \\
\boldsymbol{d}_{\text {mean }}(\mathrm{mm})\end{array}$ & $\begin{array}{c}\mathbf{d}_{[0.1]}(\mu \mathrm{m}) / \\
d_{[0.1]}(\mu m)\end{array}$ & $\begin{array}{c}\mathbf{d}_{[0.5]}(\mu \mathrm{m}) / \\
d_{[0.5]}(\mu \mathrm{m})\end{array}$ & $\begin{array}{c}\mathbf{d}_{[0.9]}(\mu \mathrm{m}) / \\
d_{[0.9]}(\mu \mathrm{m})\end{array}$ & $\begin{array}{l}\% \text { part }<10 \mu m \\
\% \text { part }<10 \mu m\end{array}$ \\
\hline CAT1 & 85.34 & 47.63 & 79.36 & 131.65 & 0.00 \\
\hline CAT1-20 & 19.73 & 1.34 & 12.15 & 49.89 & 45.70 \\
\hline CAT2 & 73.96 & 41.03 & 68.65 & 114.54 & 0.00 \\
\hline CAT2-20 & 17.56 & 0.96 & 10.17 & 45.67 & 41.57 \\
\hline CAT3 & 83.73 & 45.85 & 77.39 & 130.60 & 0.00 \\
\hline CAT3-20 & 20.26 & 1.29 & 12.52 & 51.19 & 42.34 \\
\hline CAT4 & 83.76 & 45.90 & 77.30 & 130.66 & 0.00 \\
\hline CAT4-20 & 22.01 & 1.44 & 14.65 & 54.18 & 45.15 \\
\hline CAT5 & 77.56 & 46.39 & 73.07 & 115.07 & 0.00 \\
\hline CAT5-20 & 22.21 & 1.50 & 14.10 & 55.42 & 49.65 \\
\hline
\end{tabular}

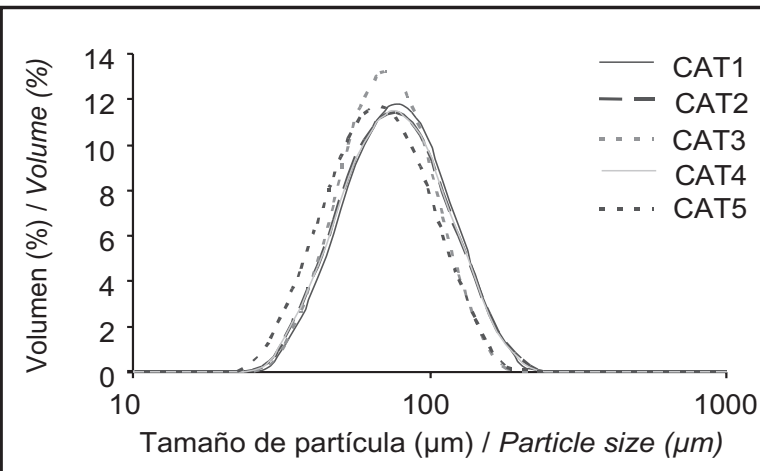

a) Residuos de catalizador originales (CATX) / a) Original state catalyst residues (CATX).

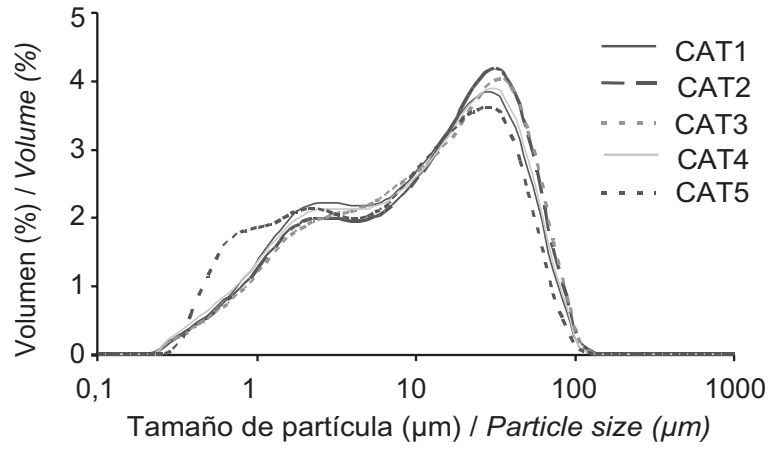

b) Residuos de catalizador molidos (CATX-20) /

b) Ground state catalyst residues (CATX-20).

Figura 2. Granulometrías de los residuos de catalizador en estado original y molido.

Figure 2. Granulometric curves for catalyst residues in their original and ground states.

\subsubsection{Espectroscopía Infrarroja de Transformada de Fourier (FTIR)}

En la Figura 3 se muestran los espectros de FTIR de todos los residuos empleados. En dicha figura se asignan las seis bandas principales del espectro según referencias bibliográficas $(18,19)$. En la zona A se encuentran las vibraciones de valencia-OH (asimétrica y simétrica), la banda $\mathrm{B}$ es debido a la vibración de deformación H-O-H. La banda marcada como $\mathrm{C}$ se atribuye a las vibraciones de valencia de los tetraedros $\mathrm{SiO}_{4}$; y como se puede observar esta banda $\mathrm{C}$ presenta un hombro sobre los $1.150 \mathrm{~cm}^{-1}$ que se atribuye a sílice amorfa polimerizada (resultado de los enlaces de los tetraedros $\mathrm{SiO}_{4}$ ). La banda D se atribuye como característica del $\mathrm{SiO}_{2}$. La banda $\mathrm{E}$ que no es muy intensa, se atribuye a los enlaces $\mathrm{Si}-\mathrm{OH}$, mientras que la banda $\mathrm{F}$ se origina por vibraciones angulares de deformación de enlaces Si-OSi. Las bandas atribuidas al aluminio son enmascaradas por las bandas de $\mathrm{SiO}_{4}$, si bien Pacewska (20) atribuye como probable asignación de la banda $\mathrm{C}$ a vibraciones de valencia de O-Si(Al)-O. Todos los catalizadores presentan espectros muy similares, por lo que no hay diferencia entre sus espectros FIIR, a pesar del diferente origen

\subsubsection{Fourier Transformed Infrared Espectroscopy (FTIR)}

In the Figure 3, the FTIR spectra for all the studied residues are shown. In this figure the six main peaks in the spectrum are assigned according to bibliographical references $(18,19)$. In the $A$ area vibrations of valency$\mathrm{OH}$ (asymmetrical and symmetrical) were found, the peak $B$ is due to the vibration of deformation $\mathrm{H}-\mathrm{O}-\mathrm{H}$. The peak $C$ is attributed to the vibrations of valency of the $\mathrm{SiO}_{4}$ tetrahedron; peak $C$ shows a shoulder at 1150 $\mathrm{cm}^{-1}$ attributed to polymerized amorphous silica (result of the connections of the $\mathrm{SiO}_{4}$ tetrahedrons). The peak $D$ is attributed to the $\mathrm{SiO}_{2}$. The peak $E$ is not very intense, and it is attributed to the Si-OH bonds, while the peak $F$ is due to angular vibrations of deformation of Si-O-Si bonds. The peaks attributed to the aluminum are masked by the peaks for $\mathrm{SiO}_{4}$, although Pacewska (20) reports as probable assignment of the peak $C$ to valency vibrations of $\mathrm{O}-\mathrm{Si}(\mathrm{Al})-\mathrm{O}$. Whole catalysts present very similar spectra, for what there is not difference among their FTIR spectra, in spite of the different origin. 


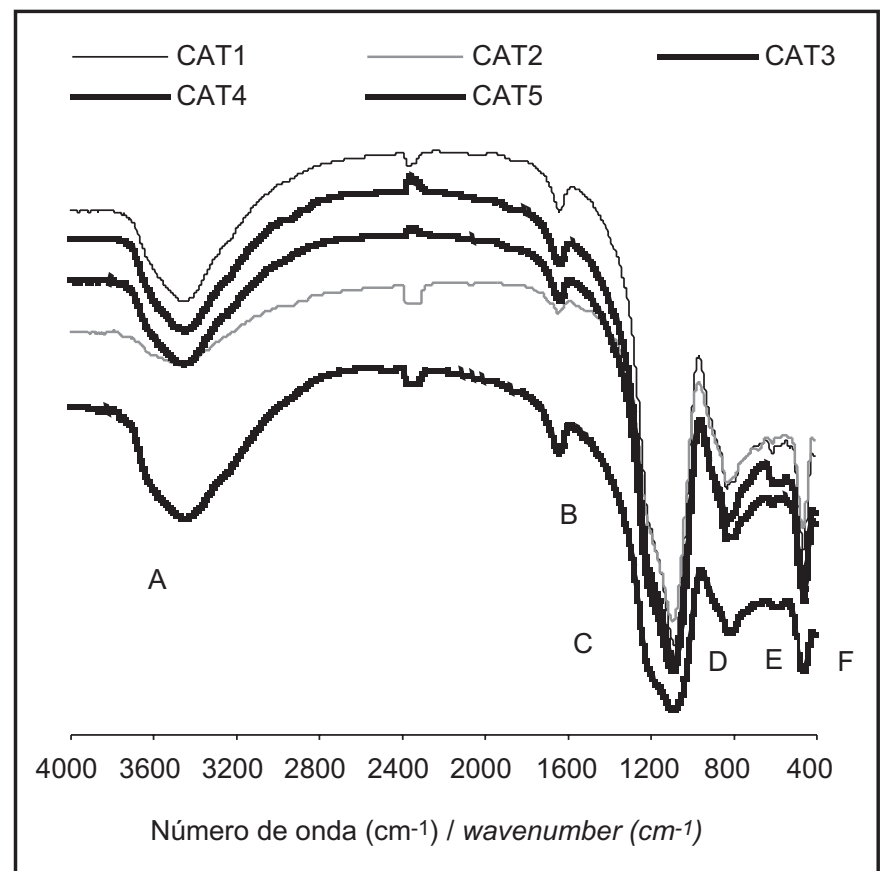

Figura 3. Espectros de FTIR de los residuos de catalizador. Figure 3. FTIR spectra for catalyst residues.

\subsubsection{Análisis térmico}

El estudio por análisis térmico de los residuos de catalizador permitió conocer si se produce algún proceso de descomposición o transformación cuando se someten a calentamiento. Las curvas termogravimétricas de los distintos catalizadores nos muestran las pérdidas de masa obtenidas al calentar las muestras de 35 a $1.000{ }^{\circ} \mathrm{C}$ en una atmósfera de aire seco. Las pérdidas de masa están por debajo del $1 \%$. La pérdida de masa fundamental se encuentra desde los 35 a los $200{ }^{\circ} \mathrm{C}$, lo que nos indica que esta pérdida se debe a la humedad que poseen las

\subsubsection{Thermal analysis}

The thermal analysis study on the catalyst residues allowed to know if some some decomposition or transformation processes take place when they undergo heating. The thermogravimetric curves for the different catalyst residues show the losses of mass obtained when heating the samples from 35 to $1000{ }^{\circ} \mathrm{C}$ in an atmosphere of dried air. The losses of mass are below $1 \%$. The main weight loss became from 35 to $200{ }^{\circ} \mathrm{C}$, what suggests that this mass loss is due to the moisture of the samples and to the residual $\mathrm{OH}$ groups from the

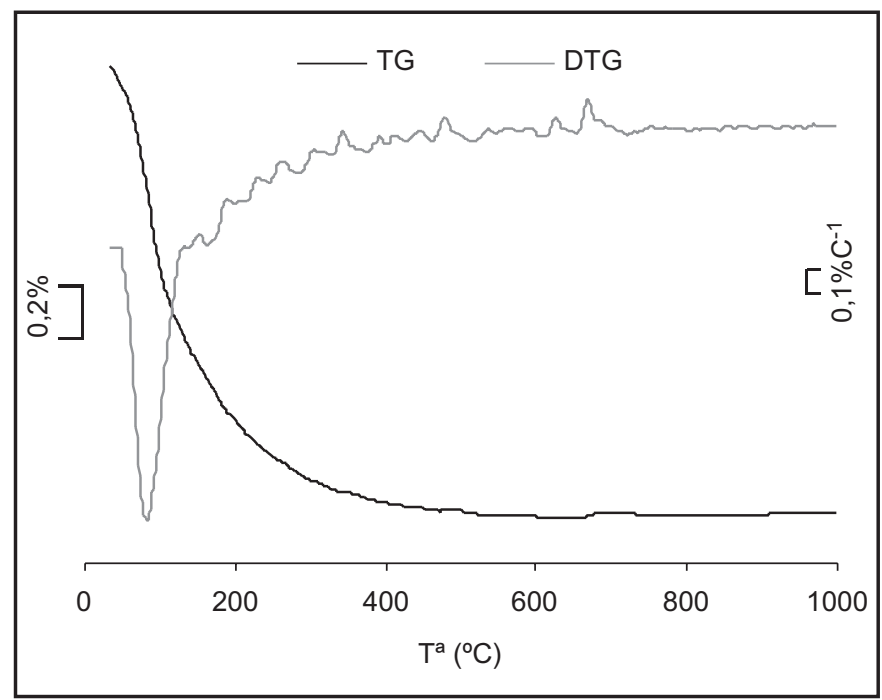

Figura 4. Curva TG y DTG del CAT1.

Figure 4. TG and DTG curves for CAT1. 
muestras y a los grupos $\mathrm{OH}$ residuales de los silicoaluminatos. Es importante destacar que en ninguno de los residuos se observó pérdidas de masa debidas a la presencia de materia orgánica o de carbón, ni a la presencia de carbonatos. En la Figura 4, a modo de ejemplo, se presentan las curvas TG, y DTG de la muestra CAT1.

\subsubsection{Microscopía electrónica (SEM)}

La microscopía electrónica fue la técnica escogida para conocer la forma, el aspecto y la textura de las partículas de residuo de catalizador en sus estados originales y molidos. En la Figura 5 se muestran, a modo de ejemplo, 6 micrografías de los residuos de catalizador. Como se puede observar en las micrografías, todos los residuos de catalizador en su estado original presentan un aspecto silicoaluminates. It is important to highlight that in none of the residues loss of mass due to the presence of organic matter or coal were observed, neither the presence of carbonates. In the Figure 4, as example, TG and DTG curves of the CAT1 sample are depicted.

\subsubsection{Scanning electronic microscopy (SEM)}

The scanning electronic microscopy was the selected technique to know the shape, the type and the surface smoothness of the particles of catalyst residue in its original and milled states. In the Figure 5, as example, six micrographies of the catalyst residues are shown. Catalyst residues in their original state present a similar aspect among them, with particles with spherical shape

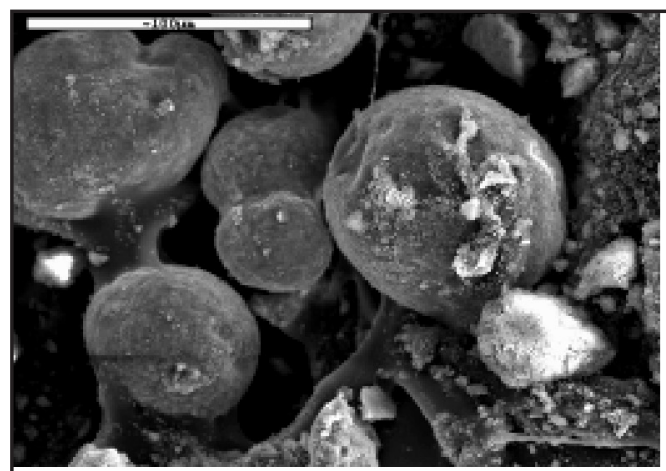

a) CAT2

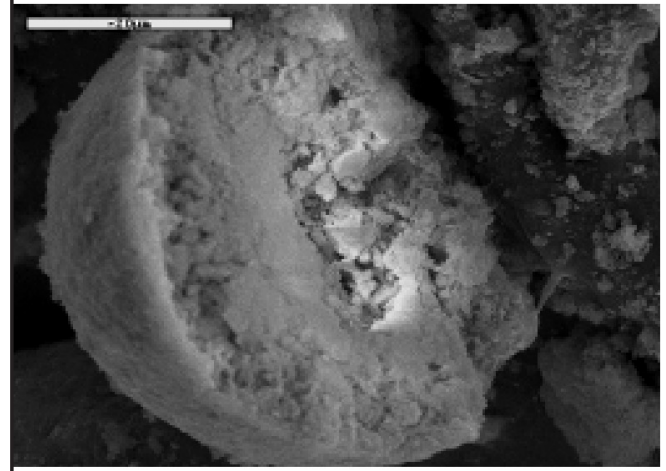

c) CAT3

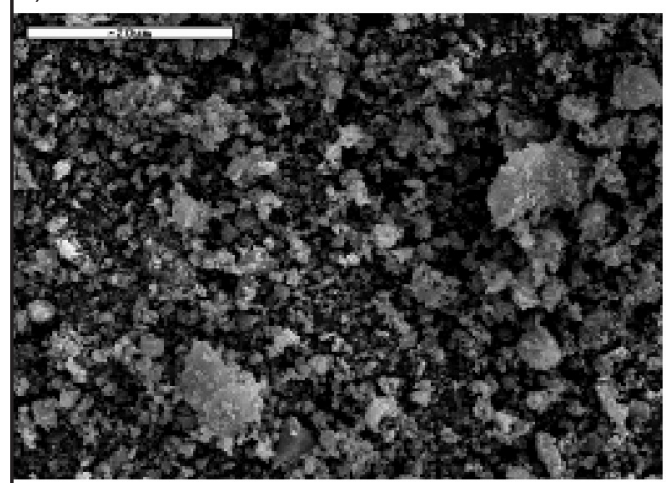

e) CAT2-20

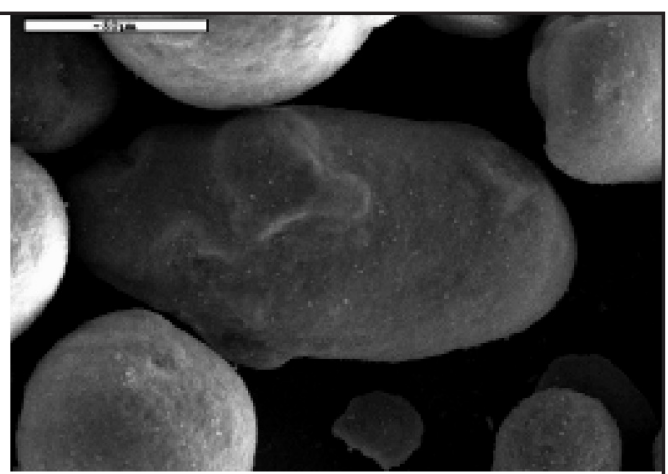

b) CAT1

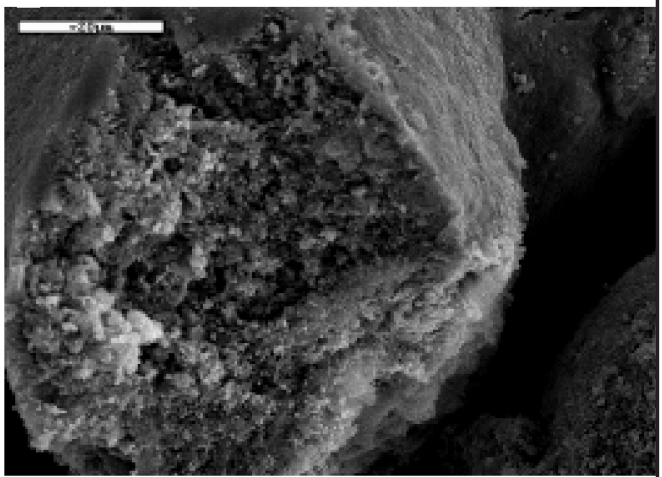

d) CAT1

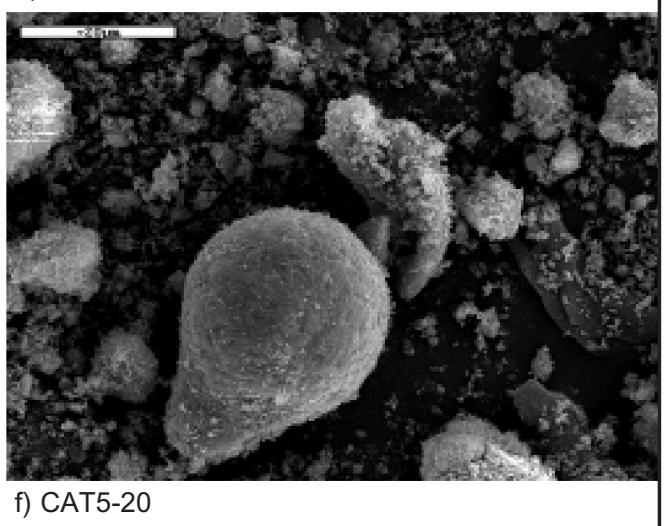

Figura 5. Micrografías realizadas por SEM de los residuos de catalizador en estado original y molidos. Figure 5. SEM micrographies of catalyst residues in original and ground states. 
similar con partículas de forma esférica (5a) o esferoidal (5b). Son partículas altamente porosas ( 5 c y $5 d$ ), lo que les confiere una gran superficie específica que, a su vez, se traduce en una alta reactividad (10).

Una vez molidos, los residuos disminuyen lógicamente de tamaño, rompiéndose en partículas irregulares (5e), aunque a veces las esferas originales de menor tamaño permanecen (5f).

\subsection{Estudios termogravimétricos en pastas. Reactividad puzolánica}

La reactividad de los distintos residuos de catalizador respecto a la fijación de hidróxido cálcico liberado en la hidratación del cemento, se ha estudiado por medio del análisis termogravimétrico de pastas cemento/CAT, a las edades de curado de 3, 7, 14 y 28 días. Para ello se preparan pastas de cemento, empleando un $15 \%$ de sustitución de cemento por los distintos residuos de catalizador, en esta experiencia se emplean los residuos de catalizador en su estado molido. La relación agua/conglomerante se fija en 0,5, entendiendo conglomerante por la suma de cemento y puzolana.

La cal fijada está en función del hidróxido cálcico $(\mathrm{CH})$ que contiene la pasta control (solo cemento). Por ello, en el cálculo del porcentaje de cal fijada por los distintos residuos de catalizador, se utiliza la siguiente expresión (21) [1]: (5a) or esferoidal shape (5b). These are highly porous particles ( $5 \mathrm{c}$ and $5 d$ ) and consequently present a large specific surface area, yielding a high reactivity (10).

Obviously, after milling, particles diminish in size, breaking in irregular shape particles (5e), although the original spherical particles of smaller size remain (5f).

\subsection{Thermogravimetric studies on pastes. Pozzolanic reactivity}

The reactivity of the different catalyst residues regarding to the fixation of calcium hydroxide generated in the hydration of the Portland cement has been studied by means of the thermogravimetric analysis of the corresponding cement/CAT pastes, to the following curing ages: 3, 7, 14 and 28 days. In this way, $15 \%$ of cement substitution by the different catalyst residues was carried out for preparing pastes, being, in this experience, milled catalyst residues. The water/binder ratio was 0.5 , being binder the sum of cement and pozzolan weights.

The fixed hydrated lime depends on the calcium hydroxide $(\mathrm{CH})$ that contains the control paste (only cement as binder). Thus, in the calculation of the percentage of hydrated lime fixed by the different

$$
\text { Cal fijada (\%) / Hydrated fixed lime (\%) }=\frac{\left|\mathrm{CH}_{C} * \mathrm{C}_{\%}\right|-\mathrm{CH}_{P}}{\left|\mathrm{CH}_{C} * \mathrm{C}_{\%}\right|} * 100
$$

donde $\mathrm{CH}_{\mathrm{C}}$ es la cantidad de $\mathrm{CH}$ en la pasta control para un tiempo de curado determinado, $\mathrm{CH}_{\mathrm{p}}$ es la cantidad de $\mathrm{CH}$ presente en la pasta con residuo de catalizador a la misma edad de curado y $\mathrm{C}_{\%}$ es la proporción de cemento presente en la pasta (en tanto por uno). Las determinaciones de $\mathrm{CH}_{\mathrm{c}}$ y $\mathrm{CH}_{\mathrm{p}}$ se obtienen realizando cálculos estequiométricos a partir de los datos de pérdida de agua en el intervalo entre $500-600{ }^{\circ} \mathrm{C}$, correspondientes a la reacción de deshidroxilación del $\mathrm{CH}$.

Los porcentajes de cal fijada por los distintos residuos de catalizador se resumen en la Tabla 4, así como el valor medio de todos ellos, y la representación gráfica de su evolución con el tiempo de curado se muestra en la Figura 6.

Se observa que existe una tendencia definida común en la fijación de cal respecto al tiempo, todas las puzolanas presentan valores que fluctúan en el intervalo del $13-36 \%$. Las pastas con residuos puzolánicos a tiempos cortos de curado (3-7 días), no presentan un aumento progresivo de fijación de cal respecto al tiempo. Este comportamiento es catalyst residues, the following expression is used (21) [1]: where $\mathrm{CHC}$ is the quantity of $\mathrm{CH}$ in the control paste for a given curing time, $\mathrm{CHp}$ is the quantity of $\mathrm{CH}$ present in the catalyst residue containing paste for the same curing age and $\mathrm{C}_{\%}$ is the cement proportion in the paste (given as a fraction of the unity). The quantities of $\mathrm{CHc}$ and $\mathrm{CHp}$ are obtained by stoichiometric calculation from the data of loss of water in the range $500-600{ }^{\circ} \mathrm{C}$, corresponding to the dehydroxilation reaction of the $\mathrm{CH}$.

The percentages of fixed hydrated lime for the different catalyst residues are summarized in Table 4, as well as the mean value, and their graphic representation of its evolution with the curing time are shown in Figure 6.

It can be observed a common defined trend in the fixation of hydrated lime versus curing time, all the pozzolans showed values that are found in the range 13$36 \%$. The pastes with pozzolanic residues at short curing times (3-7 days) do not present a progressive increase of hydrated lime fixation with time. This behavior is due to 
debido a que en estas experiencias debe tenerse en cuenta que se producen dos reacciones a la vez: la hidratación del cemento y la reacción puzolánica, por lo que la disponibilidad de $\mathrm{CH}$ y la reactividad de la puzolana da lugar a este comportamiento. Además, en muchos casos las puzolanas a tiempos cortos de curado actúan como filler, acelerando la hidratación del cemento, es decir, sirven de agentes de nucleación, donde precipitan los productos de la hidratación del cemento, de manera que éste puede seguir hidratándose $\mathrm{y}$, por lo tanto, aumentando la cantidad de $\mathrm{CH}$ presente en el sistema, y formándose una cantidad mayor de productos de hidratación. A partir de los 7 días este fenómeno deja de observarse, de modo que la cantidad de cal fijada a los 14 y 28 días aumenta de forma notable. that in these experiences it should be kept in mind that two reactions take place at the same time: the hydration of the Portland cement and the pozzolanic reaction, and consequently the availability of $\mathrm{CH}$ and the reactivity of the pozzolan give place to this behavior. Also, in many cases the pozzolan at early curing ages acts as filler, accelerating the hydration of the cement. In other words, they serve as nucleation agents, where hydration products from the cement precipitate, accelerating the cement hydration and, therefore, increasing the quantity of $\mathrm{CH}$ present in the system, and yielding a larger quantity of hydrated products. From 7 days curing time this behaviour is not observed, and the quantity of hydrated lime fixed at 14 and 28 curing days increases in a remarkable way.

Tabla 4 / Table 4

Porcentajes de cal fijada por los residuos de catalizador en las pastas CEM/CAT. Fixed hydrated lime percentages for catalyst residues in CEM/CAT pastes.

\begin{tabular}{|c|c|c|c|c|}
\hline Puzolana / Pozzolan & 3 días / 3 days & 7 días / 7 days & 14 días / 14 days & 28 días / 28 days \\
\hline CAT1-20 & 22.9 & 16.0 & 21.7 & 36.2 \\
\hline CAT2-20 & 28.3 & 24.0 & 27.7 & 35.0 \\
\hline CAT3-20 & 24.2 & 13.1 & 23.3 & 31.6 \\
\hline CAT4-20 & 26.8 & 22.2 & 30.0 & 34.5 \\
\hline CAT5-20 & 30.4 & 24.9 & 29.4 & 33.6 \\
\hline Valor medio / Mean value & $26.5 \pm 3.0$ & $20.0 \pm 5.2$ & $26.4 \pm 3.7$ & $34.2 \pm 1.7$ \\
\hline
\end{tabular}

Cuando se realiza la evaluación de las curvas termogravimétricas, se calcula el porcentaje total de pérdida de masa $\left(\mathrm{P}_{\mathrm{T}}\right.$ ) de la muestra desde los $35^{\circ} \mathrm{C}$ hasta los $600^{\circ} \mathrm{C}$ y un porcentaje de pérdida de masa debido a la deshidroxilación de la cal $\left(\mathrm{P}_{\mathrm{CH}}\right)$ en el intervalo de temperatura de 500$600{ }^{\circ} \mathrm{C}$; si se resta al porcentaje de pérdida de masa total, el porcentaje de pérdida debido a la cal presente, obtendremos el porcentaje de agua asociado a los hidratos $\left(\mathrm{P}_{\mathrm{H}}\right)$. Los datos de agua combinada de los hidratos de las pastas con puzolanas se muestran en la Tabla 5.
The total percentage of weight loss is calculated $\left(P_{T}\right)$ from the thermogravimetric curves of the sample in the range $35^{\circ} \mathrm{C}-600^{\circ} \mathrm{C}$ and also the percentage of weight loss due to the deshydroxilation of the hydrated lime $\left(P_{C H}\right)$ in the range $500-600{ }^{\circ} \mathrm{C}$; if the percentage of loss due to the present lime is subtracted to the percentage of total mass loss, the percentage of water related to the hydrates $\left(P_{H}\right)$ is obtained. The data of combined water in the hydrates in the pastes with pozzolan are shown in the Table 5.

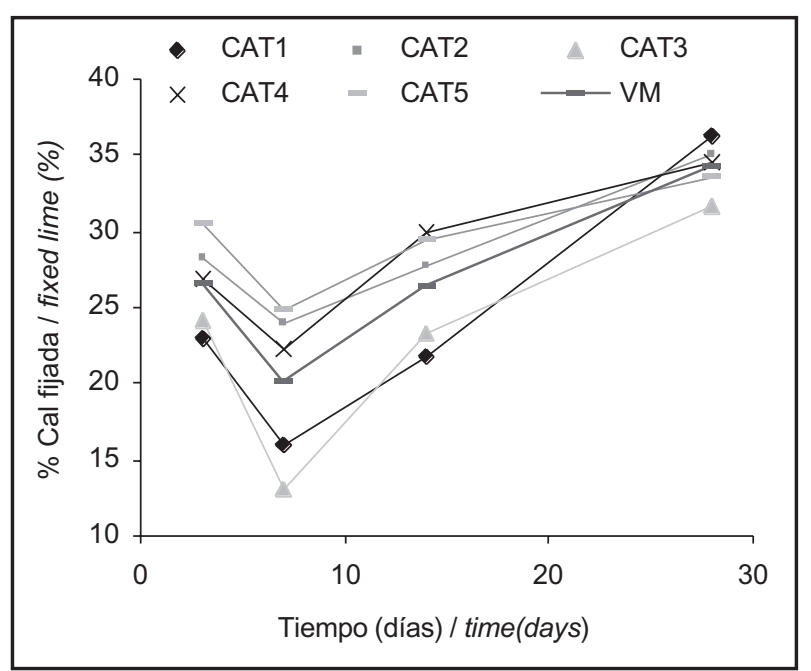

Figura 6. Evolución de la fijación de cal por los residuos de catalizador en las pastas de cemento con un 15\% de puzolana, en función del tiempo de curado (VM=valor medio).

Figure 6. Development of fixed hydrated lime by catalyst residues in cement pastes, with curing time (VM= mean value). 
Tabla 5 / Table 5

Porcentajes de agua combinada de los hidratos $\left(\mathrm{P}_{\mathrm{H}}\right)$ en las pastas a las diferentes edades de curado. Percentages of combined water in the hydrates $\left(P_{H}\right)$ in pastes at different curing ages.

\begin{tabular}{|c|c|c|c|c|}
\hline & 3 días / 3 days & 7 días / 7 days & 14 días / 14 days & 28 días / 28 days \\
\hline Control & 13.95 & 13.31 & 14.78 & 16.05 \\
\hline CAT1 & 14.17 & 15.30 & 17.05 & 18.13 \\
\hline CAT2 & 14.97 & 15.58 & 17.40 & 18.12 \\
\hline CAT3 & 15.46 & 15.20 & 17.00 & 18.37 \\
\hline CAT4 & 15.60 & 16.42 & 17.64 & 18.05 \\
\hline CAT5 & 15.83 & 16.28 & 17.34 & 18.45 \\
\hline Valor medio / Mean Value & $15.20 \pm 0.66$ & $15.75 \pm 0.56$ & $17.28 \pm 0.26$ & $18.22 \pm 0.17$ \\
\hline
\end{tabular}

Como se puede observar en la Tabla 5, para todas las edades de curado, las pastas que contienen los residuos de catalizador obtienen porcentajes de agua combinada de los hidratos superiores a la pasta control. Este dato es indicativo de que se están formando más productos de hidratación a pesar de contener menos cemento Portland y, por lo tanto, que los residuos de catalizador están actuando puzolánicamente y muy posiblemente también, acelerando la hidratación del cemento.

\subsection{Estudios mecánicos en morteros}

Como ya se comentó en el apartado experimental, se fabricaron morteros con una relación agua/conglomerante de 0,5 y el porcentaje de sustitución de cemento por puzolana molida (CATX-20) fue de un $15 \%$. Los morteros se ensayaron mecánicamente (flexotracción y compresión) a las edades de curado de 3, 7, 14 y 28 días, y como resultado dieron los valores que se indican en las Tablas 6 y 7.

Como se puede observar en la Tabla 6, las resistencias a flexotracción de todos los morteros con residuos de catalizador son muy similares entre ellas, y a su vez muy parecidas a las obtenidas por el mortero control.

En cuanto a la resistencia a compresión, se puede observar cómo a tres días de curado los morteros con residuo de catalizador no logran superar la resistencia obtenida por el mortero control, aunque los datos son muy cercanos
As can be seen in Table 5, for all the curing ages studied, the pastes that contain the catalyst residues yielded percentages of combined water higher than those found for control paste. This behaviour suggests that more quantity of hydrated products are being formed in spite of containing less Portland cement and therefore suggests the catalyst residues are playing a pozzolanic role and, probably, also, accelerating the hydration of the cement.

\subsection{Mechanical studies on mortars}

As it was already commented in the experimental section, mortars were manufactured with 0.5 water/binder ratio and the percentage of cement replacement by ground pozzolan (CATX-20) was $15 \%$ in weight. The mortars were tested mechanically (flexural and compressive tests) to the following curing ages: 3, 7,14 and 28 days, and they yielded the values that are listed in Tables 6 and 7.

As can be observed in the Table 6, the flexural strength for whole mortars with catalyst residue are very similar among them, and also very similar to those yielded for the control mortar.

Regarding compressive strength, one can observe for three days curing time that the mortars with catalyst residue are not able to overcome the strength yielded for the control mortar, although those strengths are similar

Tabla 6 / Table 6

Valores de resistencia a flexotracción de los morteros control y los morteros con los residuos de catalizadores (CATX-20). Flexural strength values for control mortar and for mortars containing catalyst residues (CATX-20).

\begin{tabular}{|c|c|c|c|c|}
\hline & 3 días / 3 days & 7 días / 7 days & 14 días / 14 days & 28 días / 28 days \\
\hline Control & $5.7 \pm 0.3$ & $6.7 \pm 0.2$ & $7.3 \pm 0.1$ & $7.6 \pm 0.2$ \\
\hline CAT1 & $6.2 \pm 0.3$ & $6.6 \pm 0.2$ & $7.2 \pm 0.4$ & $7.1 \pm 0.1$ \\
\hline CAT2 & $5.8 \pm 0.5$ & $6.6 \pm 0.1$ & $7.2 \pm 0.2$ & $6.7 \pm 0.3$ \\
\hline CAT3 & $5.7 \pm 0.3$ & $6.6 \pm 0.1$ & $7.3 \pm 0.9$ & $7.2 \pm 0,1$ \\
\hline CAT4 & $6.3 \pm 0.2$ & $6.8 \pm 0.2$ & $7.0 \pm 0.2$ & $7.0 \pm 0.4$ \\
\hline CAT5 & $6.2 \pm 0.4$ & $6.7 \pm 0.1$ & $6.9 \pm 0.6$ & $6.9 \pm 0.4$ \\
\hline Valor medio / Mean value & $6.0 \pm 0.3$ & $6.6 \pm 0.1$ & $7.1 \pm 0.2$ & $7.0 \pm 0.2$ \\
\hline
\end{tabular}


a este último. Es a partir de los siete días de curado cuando los morteros con residuo de catalizador comienzan a superar ligeramente la resistencia del mortero control, y se produce un aumento progresivo de los valores de resistencia, hasta llegar a los 28 días de curado. Estos datos confirman que los residuos de catalizador de craqueo catalítico tienen un comportamiento puzolánico importante. to this last. From seven days curing time the mortars with catalyst residue begin to overcome slightly the strength of the control mortar, and a progressive increase of the strength values takes place, until 28 days curing age. These data confirm that the catalyst residue have an important pozzolanic behavior.

Tabla 7 / Table 7

Valores de resistencia a compresión de los morteros control y los morteros con los residuos de catalizadores (CATX-20). Compressive strength values for control mortar and for mortars containing catalyst residue (CATX-20).

\begin{tabular}{|c|c|c|c|c|}
\hline & 3 días / 3 days & 7 días / 7 days & 14 días / 14 days & 28 días / 28 days \\
\hline Control & $31.1 \pm 0.8$ & $36.9 \pm 0.9$ & $41.5 \pm 1.7$ & $44.7 \pm 2.1$ \\
\hline CAT1 & $30.1 \pm 0.5$ & $37.5 \pm 0.6$ & $47.7 \pm 1.1$ & $53.7 \pm 0.7$ \\
\hline CAT2 & $31.6 \pm 0.4$ & $38.8 \pm 1.5$ & $49.0 \pm 1.5$ & $54.7 \pm 1.2$ \\
\hline CAT3 & $30.4 \pm 0.9$ & $38.0 \pm 0.8$ & $44.8 \pm 1.6$ & $55.7 \pm 2.1$ \\
\hline CAT4 & $30.1 \pm 1.1$ & $38.8 \pm 1.9$ & $48.3 \pm 2.4$ & $55.4 \pm 2.3$ \\
\hline CAT5 & $28.6 \pm 1.1$ & $36.8 \pm 1.7$ & $47.3 \pm 2.7$ & $52.2 \pm 1.3$ \\
\hline Valor medio / Mean value & $30.1 \pm 1.1$ & $38.0 \pm 0.9$ & $47.4 \pm 1.6$ & $54.3 \pm 1.4$ \\
\hline
\end{tabular}

A continuación, en la Figura 7 se representan los valores del índice de actividad resistente-IAR (22). Este índice se define como el cociente entre la resistencia del mortero con puzolana y el mortero control. Para cada edad de curado, se representa el valor medio obtenido por los morteros con los distintos residuos de catalizador, así como el valor máximo y mínimo de los morteros con dichas puzolanas.

Como se puede observar en la figura anterior, el IAR medio de todos los morteros con residuo de catalizador muestra valores superiores a la unidad para todas las edades de curado, excepto a 3 días de curado. Los datos reflejan que la actividad puzolánica de este tipo de materiales aumenta
In the Figure 7 the values of the strength activity index $I A R$ are represented (22). This index is defined as the ratio between the strength of the mortar with pozzolan and the strength of control mortar. For each curing age, the value is calculated as a mean of the strength mortars with the different catalyst residues, as well as the maximum value and minimum value of the mortars with these pozzolans are depicted.

It can be observed in the previous figure, the mean IAR values calculated from mortars with catalyst residue shows higher values than the unit for all curing ages, except for 3 days curing time. These data suggest that the pozzolanic activity of this type of materials increases

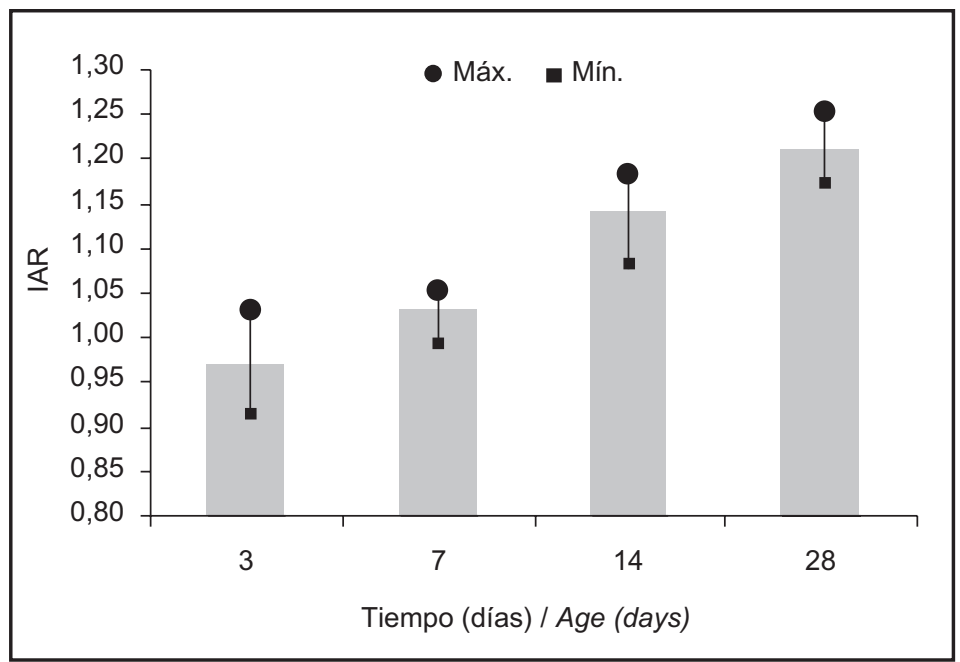

Figura 7. Evolución del índice de actividad resistente (IAR) medio, máximo y mínimo, para los morteros con residuo de catalizador a las distintas edades de curado.

Figure 7. Development of strength activity index (IAR) mean value, maximum value and minimun value, for mortars containing catalyst residue at different curing times. 
con el tiempo de curado llegando a alcanzar valores de IAR medio de 1,2; valor muy significativo que indica que se trata de materiales de alta reactividad puzolánica

\section{CONCLUSIONES}

De los estudios realizados a los cinco residuos de catalizador en cuanto a caracterización, reactividad puzolánica en pastas y resistencia mecánica en morteros, podemos concluir que el origen y los distintos procesos a los que han sido sometidos los catalizadores no provocan distinto comportamiento, ya que los cinco materiales estudiados presentan una reactividad puzolánica similar. Por ello, todos los residuos de catalizador estudiados son válidos para ser utilizados como adición mineral activa en la fabricación de morteros y hormigones.

\section{AGRADECIMIENTOS}

Los autores agradecen al Ministerio de Ciencia y Tecnología la financiación del proyecto MAT 2001-2694 y al Ministerio de Educación y Ciencia por la concesión del proyecto BIA 2004-00520, y a la co-financiación con fondos FEDER. with the curing time, reaching mean IAR values of 1,2 , a very significant value that demonstrates that it is a material of high pozzolanic reactivity.

\section{CONCLUSIONS}

From the studies carried out with the five catalyst residues on characterization, pozzolanic reactivity in pastes and mechanical strengths in mortars, we can conclude that the source and the different processing on the catalysts do not produce different behavior, since the five studied materials present a similar pozzolanic reactivity. Thus, all the studied catalyst residues become appropriate to be used as an active mineral addition in the production of mortars and concretes.

\section{ACKNOWLEDGEMENTS}

Authors thank to Ministerio de Ciencia y Tecnología of Spain teh financial support of teh Project MAT 2001-2694 and the Ministerio de Educación y Ciencia for the concession of the project BIA 2004-00520. with FEDER cofinancing.

\section{BIBLIOGRAFÍA / BIBLIOGRAPHY}

(1) Stroeven, P.; Bui, D.; Sabuni, E.: "Ash of vegetable waste used for economic production of low to high strength hydraulic binders". Fuel, vol. 78, no 2 (1999), pp. 153-159. doi:10.1016/S0016-2361(98)00143-4

(2) Sánchez de Rojas, M. I.; Frías, M.; Rivera, J.; Escorihuela, M. J.; Marín, F. P.: "Research about the pozzolanic activity of waste materials from calcined clay". Mater. Construcc., vol. 51, no 261 (2001), pp. 45-52.

(3) Goñi, S.; Guerrero, A.; Macias, M. A.; Pena, R.; Escalante, E. F.: "Secondary raw materials for synthesising new kind of cement". Mater. Construcc., vol. 51, no 263-264 (2001), pp. 71-84.

(4) Gutiérrez, P. A.; Fernández Cánovas, M.: "Efficiency coefficient of silica fume". Mater. Construcc., vol. 49, no 253 (1999), pp. 57-63.

(5) Gutiérrez, R. M. de; Delvasto, S.; Talero Morales, R.: "A new pozzolan for high performance cementitious material". Mater. Construcc., vol. 50, no 260 (2000), pp. 5-13.

(6) Frías, M.; Sánchez de Rojas, M. I.: "Influence of the metakaolin on porous structure of matrixes based in mk/cement". Mater. Construcc., vol. 50, no 259 (2000), pp. 57-67.

(7) Douglas, M.; Considine, P. E.: Tecnología del petróleo, Publicaciones Marcombo, 1977.

(8) Meyers, R. A.: Handbook of petroleum refining processes, Mc. Graw-Hill, 1996.

(9) Escardino, A.; Amorós, J. L.; Moreno, A.; Sánchez, E.: "Utilizing the used catalyst from refinery FCC units as a substitute for kaolin in formulating ceramic frits". Waste Management and Research, vol. 3, (1995), pp. 569-578.

(10) Payá, J.; Monzó, J.; Borrachero, M. V.: "Fluid catalytic cracking catalyst residue (FC3R). An excellent mineral by-product for improving early strength development of cement mixtures". Cem. Concr. Res., vol. 29 (1999), pp. 1773-1779. doi:10.1016/S0008-8846(99)00164-7 (11) Payá, J.; Monzó, J.; Borrachero, M. V.; Velázquez, S.; Soriano, L.: "Study on the properties of different spent silicoaluminous catalysts and their use in cementing mixtures". 8th CANMET, Las Vegas (2004), Supplementary papers, pp. 513-527.

(12) Payá, J.; Monzó, J.; Borrachero, M. V.; Velázquez, S.: "The chemical activation of pozzolanic reaction of fluid catalytic cracking catalyst residue (FC3R) in lime pastes". Advances in Cement Research, vol. 19, no 1 (2007), pp. 9-16. doi:10.1680/adcr.2007.19.1.9

(13) Wan-Lung Wu; Jung-Hsiu Wu; Kung-Chung Hsu: "Subproductos del fraccionamiento catalítico del petróleo: características, actividad puzolánica y su efecto en las propiedades del mortero". Cemento y Hormigón, no 850 (2003), pp. 18-25.

(14) Pacewska, B.; Wilinska, I.; Bukowska, M.; Blonkowski, G.; Nocun-Wczelik, W.: "An attempt to improve the pozzolanic activity of waste aluminosilicate catalyst". Journal of Thermal Analysis and Calorimetry, vol. 77 (2004), pp. 133-142. doi:10.1023/B:JTAN.0000033196.30760.af 
(15) García de Lomas, M.; Sánchez de Rojas, M. I.; Frías, M.: "Pozzolanic reaction of a spent fluid catalytic cracking catalyst in FCCcement mortars". Journal of Thermal Analysis and Calorimetry, vol. 90, no 2 (2007), pp.443-447. doi:10.1007/s10973-006-7921-7

(16) García de Lomas, M.; Sánchez de Rojas, M. I.; Frías, M.: Comportamiento científico-técnico de los cementos Portland elaborados con catalizador FCC, Monografía Instituto de Ciencias de la Construcción Eduardo Torroja, no 412, 2006.

(17) UNE-EN 196-1. "Métodos de ensayo de cementos. Parte I: Determinación de resistencias mecánicas". 1996.

(18) Vázquez, T.: Estudio de algunos componentes del cemento por espectroscopia infrarroja. Monografía Instituto de Ciencias de la Construcción Eduardo Torroja, no 297, 1971.

(19) Luxán, M. P.; Vázquez, T.: "The silica gel as a Standard pozzolan: its hard activity and its limitations". Il cemento, vol. 3 (1974), pp. 113-130.

(20) Pacewska, B.; Wilinska, I.; Bukowska, M.: "Hydration of Cement slurry in the Presence of Spent Cracking Catalyst". Journal of Thermal Analysis and Calorimetry, vol. 60 (2000), pp. 71-78. doi:10.1023/A:1010120518062

(21) Payá, J.; Monzó, J.; Borrachero, M. V.; Velázquez, S.: "Evaluation of the pozzolanic activity of fluid catalytic cracking catalyst residue (FC3R). Thermogravimetric analysis studies on FC3R-Portland cement pastes". Cem. Concr. Res., vol. 33 (2003), pp. 603-609. doi:10.1016/S0008-8846(02)01026-8

(22) UNE 83451:1986 EX. "Adiciones al hormigón. Cenizas volantes. Determinación del índice de actividad resistente con cemento Portland". 1986. 